\title{
Fouling mechanism elucidation in membrane bioreactors by bespoke physical cleaning
}

\author{
G. Di Bella ${ }^{1 *}$, D. Di Trapani ${ }^{2}$ and S. Judd ${ }^{3}$ \\ ${ }^{1}$ Facoltà di Ingegneria e Architettura - Università degli Studi di Enna "Kore", Cittadella universitaria, 94100 Enna, Italy \\ (E-mail: gaetano.dibella@unikore.it) \\ ${ }^{2}$ Dipartimento di Ingegneria Civile, Ambientale, Aerospaziale, dei Materiali, Università degli Studi di Palermo, Viale \\ delle Scienze, 90128 Palermo, Italy (E-mail: daniele.ditrapani@unipa.it). \\ ${ }^{3}$ Cranfield Water Science Institute, Cranfield University, Bedfordshire MK43 0AL, United Kingdom (E-mail: \\ s.j.judd@ @ cranfield.ac.uk).
}

* Corresponding author (E-mail: gaetano.dibella@unikore.it)

\section{Abstract}

Cake layer deposition on a membrane surface can determine both external and internal membrane fouling through negatively affecting the total filtration resistance while exerting a positive effect as a pre-filter. Membranes are usually subjected to a periodic cake layer removal through routine physical cleaning, specifically permeate backwashing of hollow fiber membranes, or enhanced cleaning through, for example, chemically-enhanced backwashing. Physical cake layer removal is crucial for sustaining permeability, yet the effect of different physical cleaning modes remains poorly evaluated. The present work attempts to analyze physical cake layer removal through the application of specific cleaning methods and the impact of these on the subsequent resistance. The constituent contributions to the overall resistance are appraised by means of the Resistances InSeries model, with the aim of producing a robust protocol for quantifying these discrete contributors. The results, based in part on published data, show the proposed approach to reliably determine the relative contribution of the different resistance components to within $0.1 \cdot 10^{12} \cdot \mathrm{m}^{-1}$ across a range of different bench and pilot-scale plants, confirming the resilience of the method.

Keywords: filter cake; fouling; backwashing; physical cleaning; resistance.

\section{$1 \quad$ INTRODUCTION}

Physical and chemical cleaning of MBRs to sustain permeability represents a crucial component of MBR operation (Wang et al., 2014). Physical cleaning notionally removes the loosely attached material on membrane surfaces, usually referred to as "reversible fouling", whereas the more aggressive chemical cleaning removes more tenacious materials, or "irreversible fouling" (Huyskens et al., 2011). Reported improvements in sustaining permeability through physical means have included water washing (Liang et al., 2008; Di Bella et al., 2015); ultrasonic cleaning (Li et al., 2013) high-frequency vibration (Chatzikonstantinou et al, 2016), and the use of ancillary particles for in-situ mechanical cleaning (Rosenberger et al, 2011; Shim et al, 2015; Aslam et al, 2017).

Notwithstanding these developments, the factors determining the efficacy of membrane physical cleaning have not yet been fully discerned, primarily because of the widely-acknowledged complexity of fouling itself (Le-Clech et al., 2006; Wang et al, 2014; Scholes et al, 2016; Meng et al., 2017). In particular, the role of the cake layer, and specifically how it pertains to reversible and irreversible fouling, remains contentious. According to a number of authors (Jiang et al., 2003; Mannina et al., 2016a and 2016b), a proportion of the cake layer deposited on the membrane surface can be considered "irreversible" if only removable by enhanced physical methods, such as ex-situ water flushing, mechanical cleaning, or cyclic cleaning - e.g. combined backwashing and crossflushing (Jiang et al., 2003). There should therefore be a distinction between reversible fouling removable by conventional backwashing and relaxation and that removed by the enhanced physical methods. This distinction is of practical significance, since enhanced physical methods may be preferred to the application of chemicals for recovering permeability. 
Physical washing of MBR membranes in experimental studies is usually employed for cleaning purposes, rather than for elucidation of fouling mechanisms. Few authors have used data derived from periodic physical cleaning for the analysis of fouling development and defining deposition mechanisms. In the latter context, the Resistance-In-Series (RIS) model represents one of the most extensively used approaches (Psoch and Schiewer, 2006a; Rafiei et al., 2014) since it is intuitive and allows quantification of the discrete fouling components, albeit with some limitations (Chang et al., 2001). The use of physical cleaning to define fouling components as defined by the RIS model has nonetheless been limited.

The aim of the present study is to gain insight into the usefulness of membrane physical cleaning for detailed analysis of fouling mechanisms by delineating the different components using the RIS model. The RIS model has been applied to the outputs from a protocol encompassing manual physical washing, and their reproducibility subsequently determined. The model was applied to outputs from previous studies (Di Bella et al., 2010, 2011 and 2013; Di Trapani et al., 2014 and 2015) pertaining to a range of pilot and bench scale plants of different configurations, operational conditions and feed wastewater characteristics. The system behavior in terms of removal efficiency, biomass activity and fouling propensity has been analyzed. The fouling mechanisms and development were re-evaluated using a standard computational approach to define new specific resistance values, as well validating simulated data under the range of operating conditions employed in the pilot-scale installations. Supplementary specific batch tests were performed under comparable conditions using similar membrane modules to assess the robustness of the adopted protocol with reference to the precision of the outputs.

\section{MATERIALS AND METHODS}

\subsection{Protocol and RIS model}

A bespoke physical cleaning protocol was employed to define the characteristic resistances associated with the main fouling mechanisms. The protocol was reproduced by the operator for all the plants subjected to conventional physical cleaning at least once during the plant operation. The permeate flux and transmembrane pressures (TMP) were measured during normal plant operations, prior to cleaning, the total resistance to filtration $\left(R_{t o t, 1}\right)$ being defined as:

$R_{t o t, 1}=\frac{T M P_{1}}{J_{1} \cdot \mu}$

where $J_{1}$ is the permeate flux of the fouled membrane $\left[\mathrm{m}^{3} \mathrm{~m}^{-2} \mathrm{~s}^{-1}\right], T M P_{1}$ the transmembrane pressure $[\mathrm{Pa}], \mu$ the permeate viscosity $[\mathrm{Pa} \mathrm{s}]$ at the operating temperature.

The membrane was then removed from the bioreactor and physically cleaned by (a) rinsing with tap water at 0.4-0.5 bar for 15 minutes with mild mechanical cleaning, (b) mechanical agitation in water for 5 minutes, and (c) rinsing with ultrapure water at $<0.2$ bar for a further 5 minutes. The cleaned membrane was then immersed in clean water and subjected to a normal filtration cycle (with the same operational flux, and ultimately with conventional backwashing if appropriate) to allow measurement of the resistance to filtration in clean water $\left(R_{t o t, c w}\right)$ :

$R_{t o t, c w}=\frac{T M P_{c w}}{J_{c w} \cdot \mu}$

where $J_{c w}$ and $\mathrm{TMP}_{\mathrm{cw}}$ are the permeate flux and the TMP for clean water after physical cleaning, respectively,. 
The membrane was then placed back in the bioreactor and subjected to the normal filtration cycle (with the same flux values and classical backwashing), using the same mixed liquor as in Step 1, to evaluate the final total resistance to filtration $\left(R_{t o t, 2}\right)$ :

$R_{t o t, 2}=\frac{T M P_{2}}{J_{2} \cdot \mu}$

where $J_{2}$ and $T M P_{2}$ refer to physically-cleaned membrane conditions. The total resistance $R_{t o t, 1}$ during normal operation can be expressed as:

$R_{\text {tot }, 1}=R_{m}+R_{P B}+R_{C, r e v}+R_{C, i r r}$

where $R_{m}$ and $R_{P B}$ represent the membrane pore blocking resistance contributions. The resistances $R_{t o t, c w}$ and $R_{t o t, 2}$ are given by:

$R_{\text {tot }, \mathrm{cw}}=R_{m}+R_{P B}$

$R_{\text {tot }, 2}=R_{m}+R_{P B}+R_{C, r e v}$

where:

$R_{P B}=R_{\text {tot }, \mathrm{cw}}-R_{m}$

$R_{C, \text { irr }}=R_{\text {tot }, 1}-R_{\text {tot }, 2}$

$R_{C, r e v}=R_{t o t, 2}-R_{t o t, c w}$

The cake resistance, either reversible $\left(R_{c, \text { rev }}\right)$ or irreversible $\left(R_{c, i r r}\right)$, is considered to be completely removable by physical cleaning. The superficial fraction removable by ordinary backwashing and air scouring relates to the less tenacious cake layer $\left(R_{c, \text { rev }}\right)$, while the fraction removable by manual washing is the more tenacious superficial cake layer $\left(R_{c, i r r}\right)$. The residual fouling layer, which is not removed by either ordinary backwashing or physical washing, pertains to intermediate pore blocking.

\subsection{Investigated plants}

Resistance data derived from previous studies, the main findings of which have been published elsewhere, were reprocessed to combine the outputs from the physical cleaning with the RIS model application for both hollow fibers (HF) and flat sheet (FS) membrane modules. Most of the results refer to $\sim 0.1 \mathrm{~m}^{2}$ membrane area bench scale $\mathrm{HF}$ modules scoured at aeration rate of $0.6 \mathrm{Nm}^{3} \mathrm{~m}^{-2} \mathrm{~h}^{-1}$. Under these conditions, the system hydrodynamics are widely known not to reflect those of fullscale modules due to the disproportionate impact of the headers (Kraume et al., 2009) and the conflict between the specific aeration demand and the average air upflow velocity (Verrecht et al, 2008). In the present study, new filtration batch tests were conducted on mixed liquor of known characteristics to obtain reliable and reproducible results, along with tests on larger, pilot-scale 0.93 $\mathrm{m}^{2} \mathrm{HF}$ modules air-scoured at rates of $0.5 \mathrm{Nm}^{3} \mathrm{~m}^{-2} \mathrm{~h}^{-1}$ and $0.8 \mathrm{~m}^{2} \mathrm{FS}$ modules scoured at $0.75 \mathrm{Nm}^{3}$ $\mathrm{m}^{-2} \mathrm{~h}^{-1}$ (Table 1).

The bench or pilot plants listed in Table 1 were operated in continuous mode and the membrane modules subject to ex-situ manual washing only when either the TMP reached a given threshold value suggested by the manufacturer or the operational conditions of the plant were expressly changed. These data refer to single washing operations and to the conditions prior to and immediately after physical cleaning (Equations 1-9). The proposed approach then enabled comparison of the fouling tendency as well elucidation of the main fouling mechanisms of the different MBR systems and quantifying the impact of the enhanced physical cleaning. Recorded data include mixed liquor composition - the suspended solids (SS), extracellular polymeric 
substances (EPSs) and salinity - along with the values for the total resistance $\left(R_{t o t}\right)$, and the discrete resistance values associated with pore blocking $\left(R_{P B}\right)$ and the reversible and irreversible cake layer $\left(R_{C, \text { rev }}\right.$ and $\left.R_{C, i r r}\right)$. The RIS model was applied during the ordinary physical washing employed during normal pilot plant operation.

Physical cleaning of either bench or pilot scale plants were carried out following filtration periods characterized by the same operating conditions at pseudo-steady state. Key recorded parameters comprised:

- average MLSS concentration, relating to reversible superficial deposition (i.e. removable by ordinary backwashing);

- average specific EPS concentration in the mixed liquor (per gram of SS), relating to irreversible (internal and superficial) fouling;

- mean filtration period, the elapsed time $t_{0}$ between previous physical cleaning, prolonged filtration directly influencing superficial and/or internal irreversible fouling );

- instantaneous permeate flux.

The bench or pilot plants investigated were fed with real municipal wastewater (Di Bella et al., 2010; Di Bella et al., 2011; Cosenza et al., 2013a,b), high strength synthetic wastewater characterized by a sharp salinity increase (Di Bella et al., 2013), and synthetic wastewater characterized by a gradual salinity increase (Di Trapani et al., 2014). For the plant $M B R_{l}$, two different mean filtration time values ( $t_{0}$ in days) were employed following the final physical clean, whereby $M B R_{1,1}$ refers to $\mathrm{t}_{0}=7 \mathrm{~d}$ while $M B R_{1,2}$ to $\mathrm{t}_{0}=10 \mathrm{~d}$ (Figure 1).

Supplementary batch tests (denoted " $B T^{\text {’) }}$ were carried out using a $15 \mathrm{~L}$ stirred cell, with aeration at $\sim 4 \mathrm{~L} \mathrm{~min}^{-1}$ and fitted with a $0.093 \mathrm{~m}^{2} \mathrm{HF}$ membrane module. These tests were operated at a constant flow rate of $\sim 1 \mathrm{~L} \mathrm{~h}^{-1}$ and intended both to identify fouling mechanisms and assess data reproducibility under the following conditions:

i. no protective cake layer $\left(B T_{1}\right)$, through filtering the wastewater for 15 minutes with routine backwashing (Table 1);

ii. pre-formed protective cake layer $\left(B T_{2}\right)$, through filtering the mixed liquor under the same conditions as (i);

iii. irreversible superficial deposition $\left(B T_{3}\right)$, through filtering the mixed liquor without routine backwashing.

Batch tests were replicated at least twice and data reported as averaged values.

\section{$3 \quad$ RESULTS}

\subsection{Bench scale plants}

Resistance values recorded for MLSS, $J$ and $\mathrm{t}_{0}$ values ranging from 4.2 to $7.2 \mathrm{gTSS} \mathrm{L}^{-1}, 15-18 \mathrm{~L} \mathrm{~m}^{-2}$ $\mathrm{h}^{-1}$ and 7-15 days respectively are shown for two different wastewaters in Figure 1 for $\mathrm{MBR}_{1}$, $\mathrm{MBR}_{2 \mathrm{~A}}$ and $\mathrm{MBR}_{2 \mathrm{~B}}$, where:

1. influent salinity was changed from 0 to $2.5 \mathrm{gNaCl} \mathrm{L}^{-1}$ for $\mathrm{MBR}_{2 \mathrm{~A}}$ (Figure 1b), hence indexed $\mathrm{MBR}_{2 \mathrm{~A}, 1}$ and $\mathrm{MBR}_{2 \mathrm{~A}, 2}$ respectively, and

2. a reduced/variable mixed liquor EPS concentration (Figure 1c) was generated, referring to filtration tests performed with more saline wastewater $\left(>2.5 \mathrm{gNaCl} \mathrm{L}^{-1}\right)$ on $\mathrm{MBR}_{2 \mathrm{~B}}$, hence indexed $\mathrm{MBR}_{2 \mathrm{~B}, 1}$ and $\mathrm{MBR}_{2 \mathrm{~B}, 2}$ respectively for $\mathrm{EPS}$ concentrations of 111 and $17 \mathrm{mg} \mathrm{L} \mathrm{L}^{-1}$, respectively. 
Table 1: Summary of the investigated test conditions

\begin{tabular}{|c|c|c|c|c|c|c|c|}
\hline ID & Experimental apparatus & $\begin{array}{c}\text { MLSS } \\
\left(\mathrm{gTSS} \mathrm{L}^{-1}\right)\end{array}$ & $\begin{array}{c}\text { EPS } \\
\left(\mathrm{mg} \mathrm{g}^{-1} \mathrm{TSS}\right)\end{array}$ & $\begin{array}{l}\text { Operational } \\
\text { condition }\end{array}$ & \multicolumn{3}{|c|}{ Membrane module features } \\
\hline $\mathrm{MBR}_{1}$ & $\begin{array}{l}\text { Bench scale plant fed with high Organic } \\
\text { Loading Rate synthetic wastewater } \\
\text { (Di Bella et al., 2013) }\end{array}$ & $7.2 \pm 0.2$ & $250 \pm 10$ & $\begin{aligned} T_{c o n .} & =1 \mathrm{minh} \\
Q_{\text {suz }} & =1 \mathrm{~L} / \mathrm{h} \\
Q_{c o n} & =2.5 \mathrm{~L} / \mathrm{h} \\
H R T & =18 \mathrm{~h} \\
S R T & =30 \mathrm{~d}\end{aligned}$ & $\begin{array}{l}\text { Hollow fiber module } \\
\qquad(P V D F)\end{array}$ & $\begin{array}{c}0.093 \mathrm{~m}^{2} \text { membrane area } \\
\text { surface }\end{array}$ & $\begin{array}{l}\text { Membrane submerged } \\
\text { in } 24 L \text { bioreactor tank }\end{array}$ \\
\hline $\mathrm{MBR}_{2 \mathrm{~A}}$ & $\begin{array}{l}\text { Bench scale plant for special synthetic } \\
\text { wastewater under different operational } \\
\text { condition (in terms of salinity and EPS } \\
\text { concentration) (Di Trapani et al., 2014) }\end{array}$ & $5.2 \pm 0.1$ & $119 \pm 3$ & $\begin{array}{c}t_{\text {suz. }}=4 \mathrm{~min} . \\
t_{c \text { con. }}=1 \mathrm{~min} . \\
Q_{\text {suz }}=1 \mathrm{~L} / \mathrm{h} \\
Q_{c o n}=2.5 \mathrm{~L} / \mathrm{h} \\
H R T=14-16 \mathrm{~h} \\
S R T=33.5-36.5 \mathrm{~d}\end{array}$ & $\begin{array}{l}\text { Hollow fiber module } \\
\quad(P V D F)\end{array}$ & $\begin{array}{c}0.093 \mathrm{~m}^{2} \text { membrane area } \\
\text { surface }\end{array}$ & $\begin{array}{l}\text { Membrane submerged } \\
\text { in } 24 L \text { bioreactor tank }\end{array}$ \\
\hline $\mathrm{MBR}_{3 \mathrm{~A}}$ & $\begin{array}{l}\text { Pilot plant for municipal wastewater, } \\
\text { started-up without (A) or with (B) } \\
\text { inoculum (Di Bella et al., 2010) }\end{array}$ & $16.6 \pm 1.1$ & n.a. & $\begin{aligned} t_{\text {suz. }} & =9 \mathrm{~min} . \\
t_{\text {con. }} & =1 \mathrm{~min} . \\
Q_{\text {suz }} & =22 \mathrm{~L} / \mathrm{h} \\
Q_{c o n} & =35 \mathrm{~L} / \mathrm{h} \\
H R T_{A, B} & =10 \mathrm{~h} \\
S R T_{A} & =\infty S R T_{B} \\
& =35 \mathrm{~d}\end{aligned}$ & $\begin{array}{l}\text { Hollow fiber module } \\
\quad(P V D F)\end{array}$ & $\begin{array}{c}0.93 \mathrm{~m}^{2} \text { membrane area } \\
\text { surface }\end{array}$ & $\begin{array}{l}\text { Membrane submerged } \\
\text { in } 190 \text { L bioreactor } \\
\text { tank }\end{array}$ \\
\hline $\mathrm{MBR}_{4}$ & $\begin{array}{l}\text { Pilot plant UCT-MBR For Nitrogen and } \\
\text { Carbon removal from municipal } \\
\text { wastewater, (Cosenza et al., 2013a,b) }\end{array}$ & $5.7 \pm 0.3$ & n.a. & $\begin{array}{c}t_{\text {suz. }}=9 \mathrm{~min} . \\
t_{\text {con. }}=1 \mathrm{~min} . \\
Q_{s u z}=22 \mathrm{~L} / \mathrm{h} \\
Q_{c o n}=35 \mathrm{~L} / \mathrm{h} \\
H R T=15 \mathrm{~h} \\
S R T=35 \mathrm{~d}\end{array}$ & $\begin{array}{l}\text { Hollow fiber module } \\
\quad(P V D F)\end{array}$ & $\begin{array}{c}0.93 \mathrm{~m}^{2} \text { membrane area } \\
\text { surface }\end{array}$ & $\begin{array}{l}2 \text { identical membranes } \\
\text { submerged in } 52 L \\
\text { bioreactor tank }\end{array}$ \\
\hline $\mathrm{MBR}_{5}$ & $\begin{array}{l}\text { Pilot plant for Nitrogen and Carbon } \\
\text { removal from municipal wastewater (Di } \\
\text { Bella et al., 2011) }\end{array}$ & $7.45 \pm 0.05$ & $43.2 \pm 0.1$ & $\begin{array}{l}Q_{s u z}=20 \mathrm{~L} / \mathrm{h} \\
H R T=15 \mathrm{~h} \\
S R T=\infty\end{array}$ & $\begin{array}{l}\text { Flat sheet module } \\
\qquad(P V D F)\end{array}$ & $\begin{array}{c}3.5 \mathrm{~m}^{2} \text { membrane area } \\
\text { surface }\end{array}$ & $\begin{array}{c}1 \text { membrane module } \\
\text { submerged in "ex-situ" } \\
\text { Bioreactor } \\
\text { configuration } \\
\end{array}$ \\
\hline$B T_{1}$ & $\begin{array}{l}\text { Batch test filtration of municipal } \\
\text { wastewater }\end{array}$ & 0.42 & n.a. & $\begin{aligned} t_{\text {suz: }} & =4 \mathrm{~min} \\
t_{\text {con. }} & =1 \mathrm{~min} \\
Q_{\text {suz }} & =1 \mathrm{~L} / \mathrm{h} \\
Q_{c o n} & =2.5 \mathrm{~L} / \mathrm{h}\end{aligned}$ & $\begin{array}{l}\text { Hollow fiber module } \\
\quad(P V D F)\end{array}$ & $\begin{array}{c}0.093 \mathrm{~m}^{2} \text { membrane area } \\
\text { surface }\end{array}$ & $\begin{array}{l}2 \text { membranes } \\
\text { submerged in single } \\
\text { stirred tank }\end{array}$ \\
\hline$B T_{2}$ & Batch test filtration of activated sludge & 6 & 150 & $\begin{aligned} t_{\text {suz. }} & =4 \mathrm{~min} . \\
t_{c o n .} & =1 \mathrm{~min} . \\
Q_{s u z} & =1 \mathrm{Lhh} \\
Q_{c o n} & =2.5 \mathrm{~L} / \mathrm{h}\end{aligned}$ & $\begin{array}{l}\text { Hollow fiber module } \\
\quad(P V D F)\end{array}$ & $\begin{array}{c}0.093 \mathrm{~m}^{2} \text { membrane area } \\
\text { surface }\end{array}$ & $\begin{array}{l}2 \text { membranes } \\
\text { submerged in single } \\
\text { stirred tank }\end{array}$ \\
\hline$B T_{3}$ & Batch test filtration of activated sludge & 6 & 150 & $\begin{array}{l}t_{s u z:}=15 \mathrm{~min} \\
Q_{s u z}=1 \mathrm{~L} / \mathrm{h}\end{array}$ & $\begin{array}{l}\text { Hollow fiber module } \\
\quad(P V D F)\end{array}$ & $\begin{array}{c}0.093 \mathrm{~m}^{2} \text { membrane area } \\
\text { surface }\end{array}$ & $\begin{array}{c}2 \text { membranes } \\
\text { submerged in single } \\
\text { stirred tank }\end{array}$ \\
\hline
\end{tabular}

$\mathrm{t}_{\mathrm{suz}}=$ Suction Time; $\mathrm{t}_{\mathrm{con}}=$ Backwashing Time; $\mathrm{Q}_{\mathrm{suz}}=$ Suction flow; $\mathrm{Q}_{\mathrm{con}}=$ Backwashing Flow; $\mathrm{n} . \mathrm{a} .=$ not analyzed. The "A" and "B" subscripts refer to different phases of experimentation 

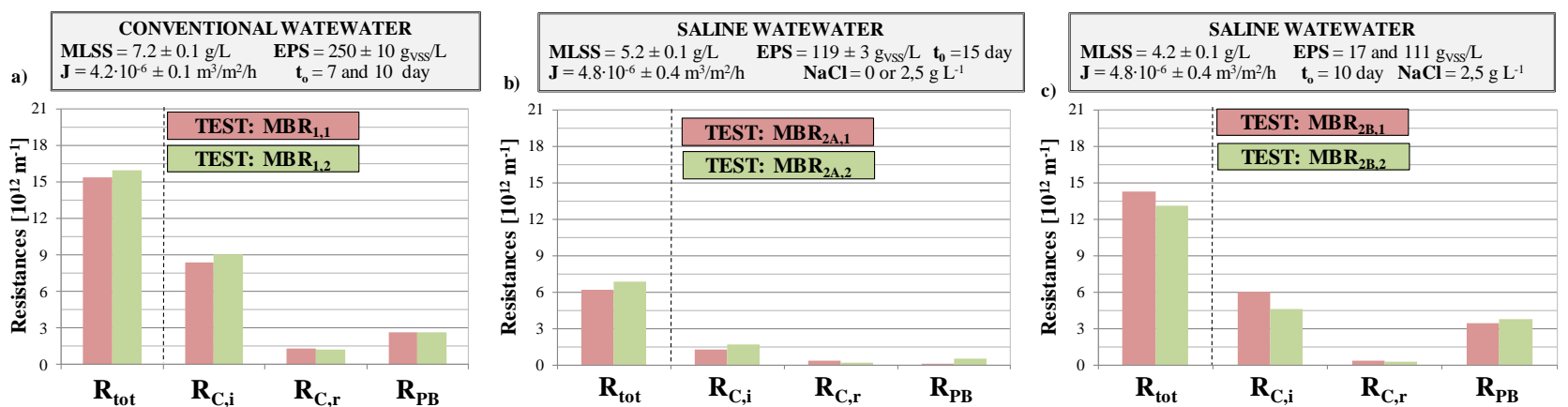

Figure 1: Outputs of RIS model applied to (a) $\mathrm{MBR}_{1}$ (b) $\mathrm{MBR}_{2 \mathrm{~A}}$, and (c) $\mathrm{MBR}_{2 \mathrm{~B}}$ for different operational conditions.

??CORRECT (a) SPELLING "WASTEWATER", AND (b) COMMA DECIMAL POINT “2.5" FOR NaCl CONCENTRATION IN THE ABOVE FIGURES.

\subsection{Pilot scale plants}

Plants studied comprised (Table 1):

- $\mathrm{MBR}_{3}$ - designed for organic matter removal, aimed at evaluating the effect of different start-up strategies (Di Bella et al., 2010),

- $\mathrm{MBR}_{4}$ - dual-module HF MBR plant designed for nutrient removal (Cosenza et al., 2013a), and

- $\mathrm{MBR}_{5}$ - FS MBR plant designed for organic matter and nitrogen removal (Di Bella et al., 2011).

$\mathrm{MBR}_{3}$ was fitted with modules with dimensions at least one order of magnitude greater than the bench scale ones and was operated in continuous mode. The original approach adopted for the resistance evaluation employed a general RIS model not encompassing periodic physical cleaning. The analysis of specific filtration cycles, as reported by Di Bella et al. (2010) and adapted from Jiang et al. (2003), was used for the evaluation of both reversible and irreversible resistances. After 52 days of operation following the start-up (with and without sludge inoculum) a single physical clean was carried out, applying an identical protocol to that described in Section 2.1 but without the mechanical agitation in water for 5 minutes (step $b$ of the above physical cleaning protocol).

Figures 2 and 3 report the RIS model outputs (Equations 7-9) from pilot plant trials using the manual washing procedure (Figures $2 \mathrm{a}$ and $3 \mathrm{a}$ ) alongside those from the original approach (Figures $2 \mathrm{~b}$ and $3 \mathrm{~b}$ ) proposed by Di Bella and co-workers (Di Bella et al., 2010). Figures $2 \mathrm{c}$ and $3 \mathrm{c}$ depict the instantaneous resistance trends during a single filtration cycle, Figure 2 referring to start-up without sludge inoculum as compared to with sludge inoculum (Figure 3). Accordingly, Figure 2 and 3 reveal different resistance trends attributable to the different start-up conditions.

Figure 4 reports the RIS model outputs from manual washing on two different days for pilot plant $\mathrm{MBR}_{4}$ (Cosenza et al., 2013a.b), where tests A and B refer to different membrane modules. Figure 5 depicts duplicate tests on FS modules for the same $t_{0}$ value. Reproducibility of the RIS model outputs was appraised by triplicate batch filtration tests of two HF modules, A and B, submerged in the same tank filtering mixed liquors of different characteristics (Figure 6). 

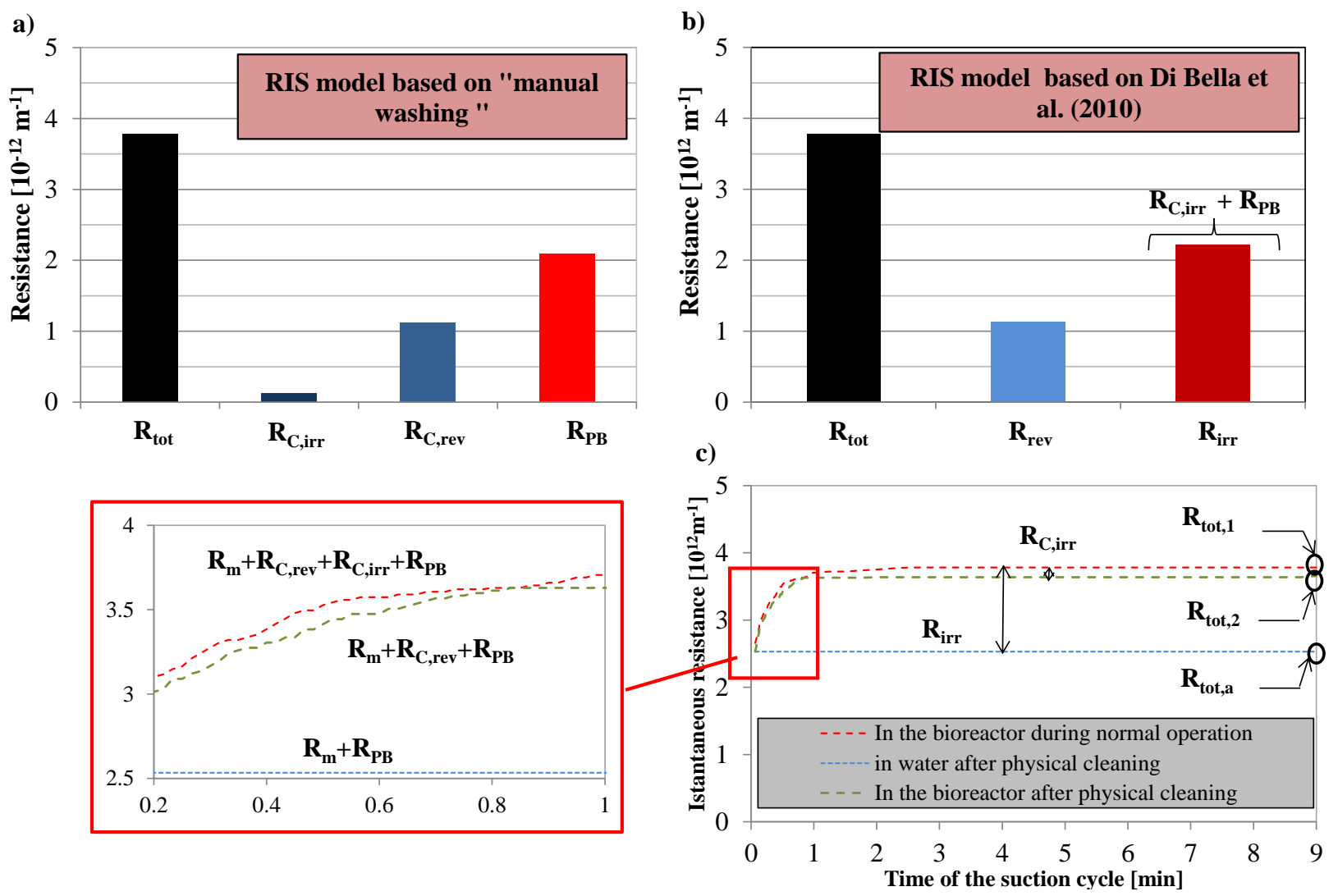

Figure 2. Comparison between RIS model based on (a) manual washing, and (b) the RIS model of Di Bella et al. 2010. (c) Instantaneous resistance variations during the test. Data refer to pilot plant started-up without sludge inoculum.
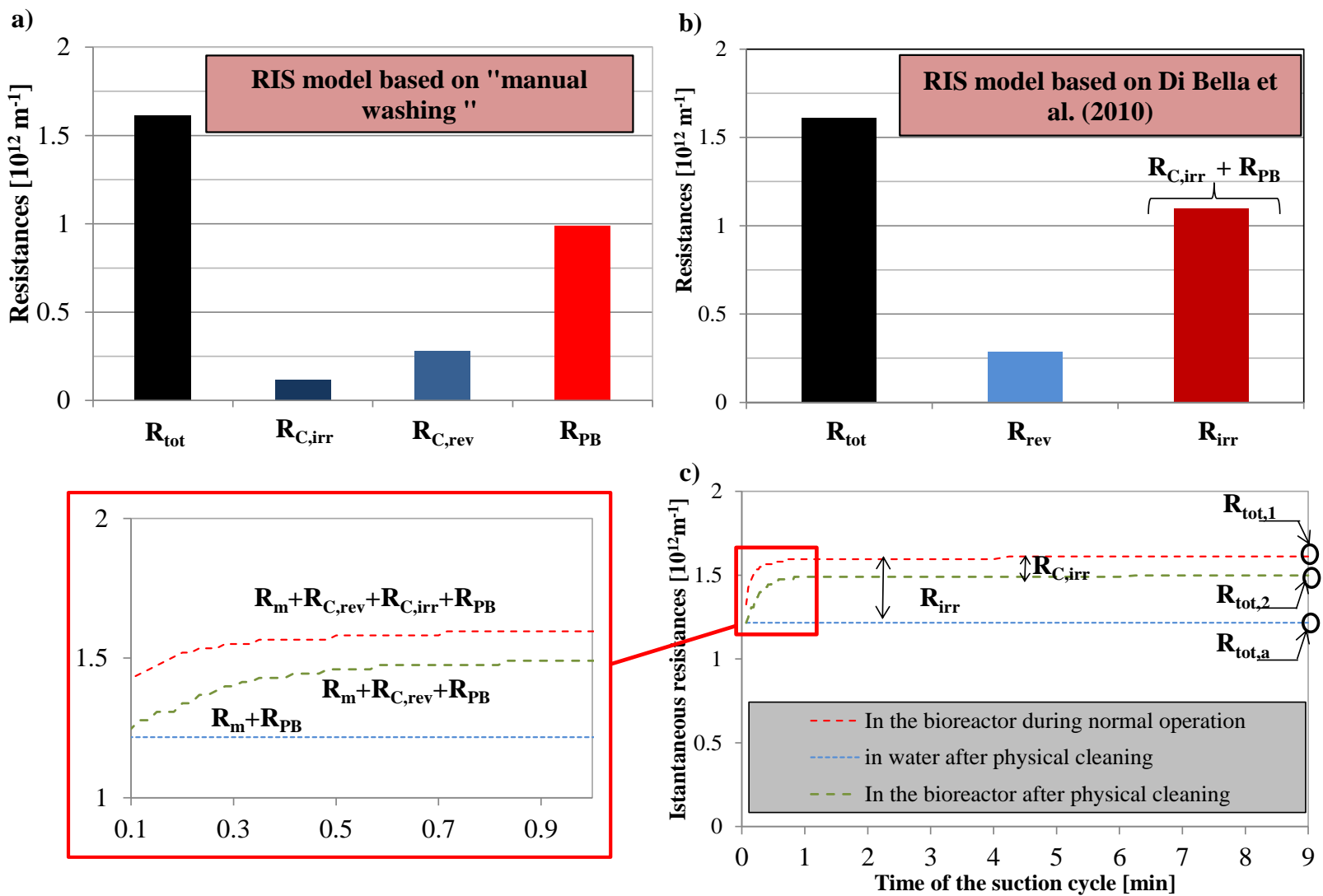

Figure 3. Comparison between RIS model based on (a) manual washing, and (b) the RIS model of Di Bella et al. 2010. (c) Instantaneous resistance variations during the test. Data refer to pilot plant started-up with sludge inoculum. ??REMOVE INVERTED COMMAS ("MANUAL WASHING”). USE UPPER CASE FOR “In” 
a)

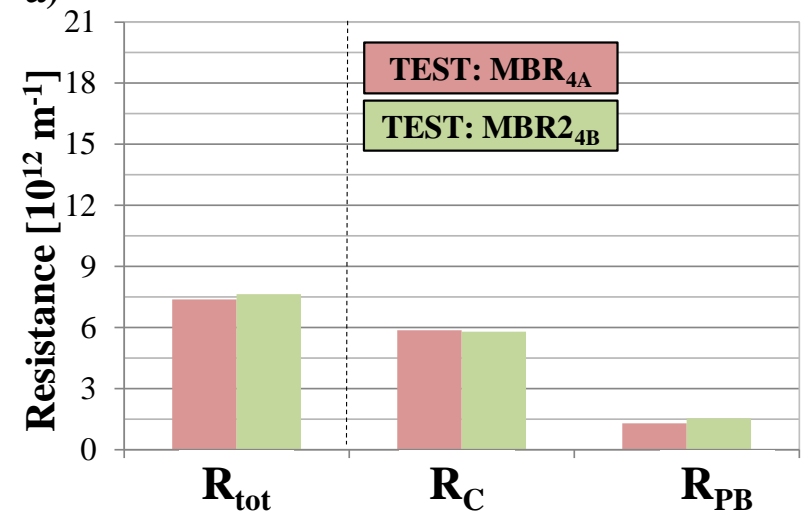

b)

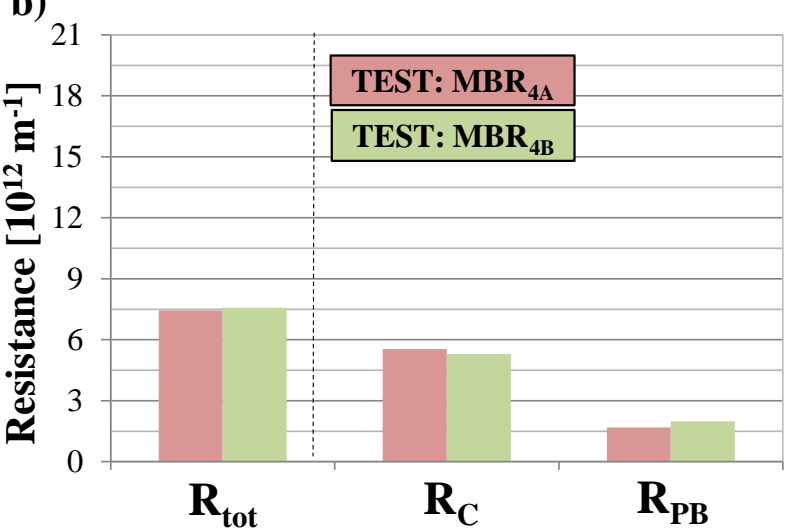

Figure 4. Replicates of resistance data calculated by means of RIS model application based on manual washing in $\mathrm{MBR}_{4}$, at experimental day 21 (a) and 36 (b), respectively (two different membrane modules " $\mathrm{A}$ " and " $\mathrm{B}$ " subject to physical cleaning) (Cosenza et al., 2013a,b).

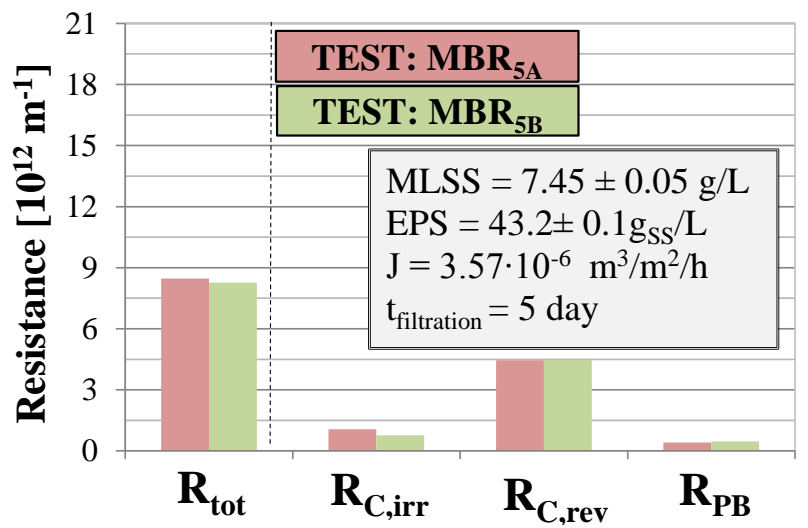

Figure 5. Results of RIS model application to flat sheet (FS) membrane in the pilot plant MBR5 (Di Bella et al., 2011).
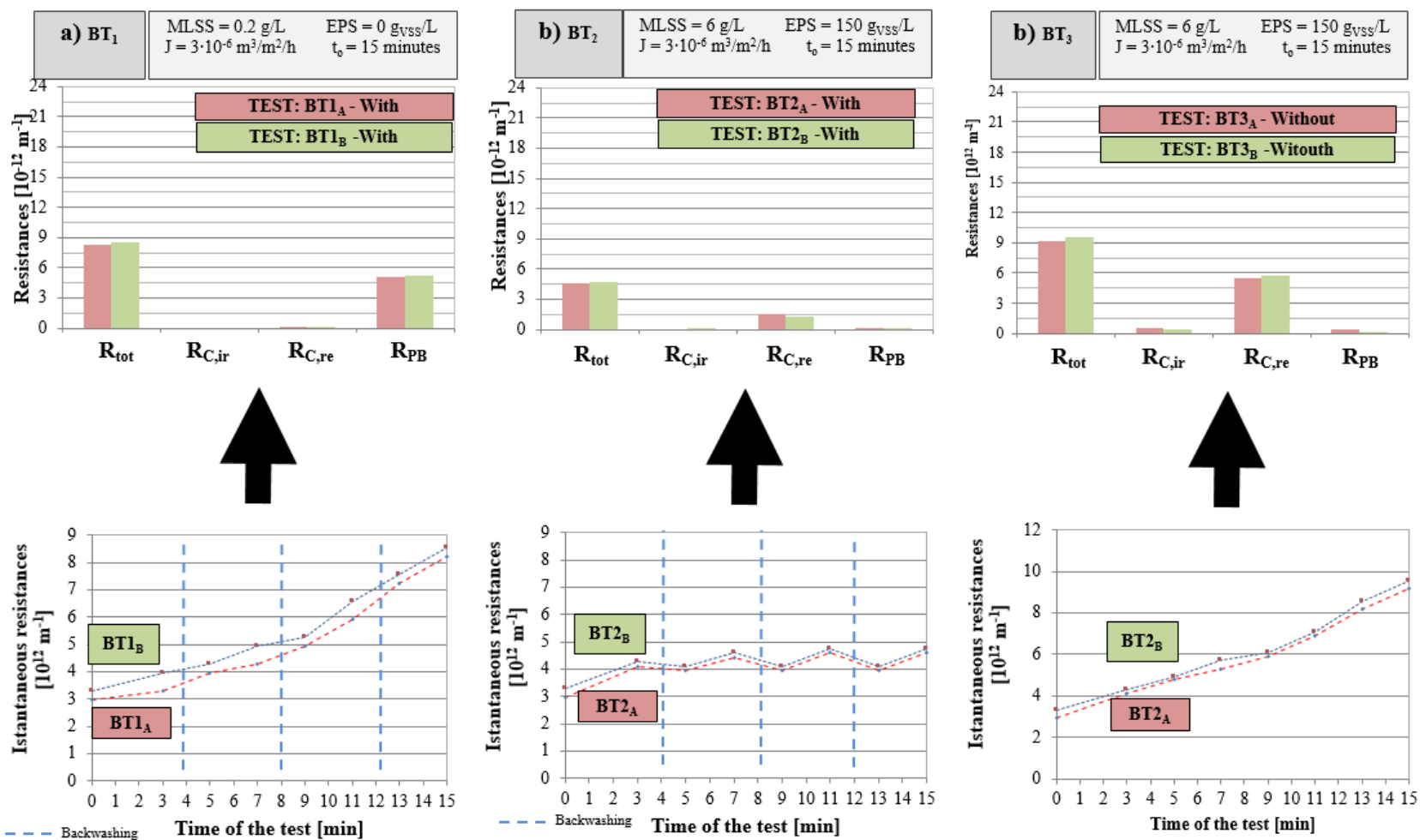

Figure 6. Batch tests for RIS model validation for the filtration of (a) raw wastewater, mixed liquor (b) with or (c) without backwashing 


\section{DISCUSSION}

\subsection{Validation and utility of method}

The effects of physical cleaning on the membrane module of $\mathrm{MBR}_{1}$ were evaluated for the filtration period characterized by similar mean MLSS and EPS concentration values. As expected, membrane fouling following 7 or 10 days of continuous operation under similar operational conditions is comparable $\left(\mathrm{R}_{\mathrm{tot}}=15.3-15.9 \times 10^{12} \mathrm{~m}^{-1}\right.$, Figure 1a). Consequently, the fouling mechanisms (reversible/irreversible cake deposition and pore blocking) can be assumed to be similar, as corroborated by the RIS outputs based on the manual washing protocol (Figure 1a). The coefficient of variation $(\mathrm{CV})$ of the achieved results was $0.03,0.06,0.05$ and 0.004 for $\mathrm{R}_{\text {tot }}, \mathrm{R}_{\mathrm{C} \text {,irr }}$, $\mathrm{R}_{\mathrm{C} \text {,rev }}$ and $\mathrm{R}_{\mathrm{PB}}$, respectively, confirming the reliability and reproducibility of the approach for quantifying the different fouling contributors.

Similarly, the outputs from $\mathrm{MBR}_{2 \mathrm{~A}}$ and $\mathrm{MBR}_{2 \mathrm{~B}}$, following two physical cleanings (analogous to $\mathrm{MBR}_{1}$ ) indicate good reproducibility of salinity-induced fouling, previously shown to be related to EPS release (Reid et al, 2006; Lin et al., 2014). In the current study, a moderate increase in the wastewater salinity from 0 to $2.5 \mathrm{gNaCl} \mathrm{L}{ }^{-1}$ increased external and internal irreversible fouling, $R_{C, i r r}$ and $R_{P B}$ respectively, by $34 \%$ and $430 \%$ (Figure $1 \mathrm{~b}$ ) between Day 15 and Day 29 (Di Trapani et al., 2014). This compares with a decrease in overall permeability of $13-15 \%$ recorded by Reid and co-workers for a salt shock of 0 to $4-5 \mathrm{gNaCl} \mathrm{L}^{-1}$ (Reid et al., 2006), attributed to an increase in the soluble microbial product (SMP) which has been shown to cause severe pore clogging fouling (Lin et al., 2014). An increase in specific EPS concentration from 17 to $111 \mathrm{mg} \mathrm{g}^{-1}$ VSS under similar conditions of MLSS, $\mathrm{J}$ and $\mathrm{t}_{0}$ was associated with a $23 \%$ decrease in $R_{C, \text { irr }}$ and a corresponding 9.4\% increase in $R_{P B}$ (Figure 1c), reflecting the protective "pre-filtering" properties of the cake layer. Against this, compared to the previous condition (Figure 1b), the variation in EPS concentration apparently leads to the formation of a more heterogeneous surface deposit, impairing pre-filtering and generally increasing the specific resistance value despite similar operating conditions and a lower $t_{0}$.

The above results highlight the usefulness and effectiveness of the proposed protocol for rigorous resistance delineation. Previous studies have defined the role of each fouling mechanism, with many identifying cake formation as predominant reversible fouling contributor, particular with reference to the pre-filter effect (Chang et al., 2001; Maartens et al., 2002; Le Clech et al., 2006; Rafiei et al., 2014; see also section 4.2). However, very few studies have exploited routine physical washing conducted as part of the plant operation to extend the fouling analysis, as with the current study. This approach appears to have been limited to one recent study of an anaerobic MBR (Ruigómez et al., 2017), whereby fouling was analyzed through resistance data determined before and after physical cleaning of the bench scale plant to corroborate results from ad-hoc batch filtration tests.

\subsubsection{Pilot scale plants}

Trends shown in Figure 2 indicate that the two RIS models offer a coherent fouling analysis. Physical manual washing (Figure 2a) isolates the resistance value deriving from the irreversible superficial deposition $\left(R_{C, i r r}\right)$, whilst for the study of Di Bella et al. (2010) (Figure 2b) this contribution is incorporated in the irreversible fouling component $R_{i r r}$ which encompasses both internal and superficial fouling. $R_{C, \text { rev }}$ is incorporated into the generic reversible fouling contribution $R_{\text {rev }}$. As previously mentioned, the two approaches can be combined using data deriving from the specific filtration cycle analysis (Di Bella et al., 2010), through Eqs 8-9.

The result is also consistent with the observed trend from the start-up with sludge inoculum (Figure 3 ). In this case, after a pre-determined filtration time (52 days) a physical clean was conducted to 
allow evaluation of the different resistance contributions and the reliability of the RIS model based on manual washing. This test indicated greater irreversible cake layer accumulation $\left(R_{C, i r r}\right)$ on the membrane surface, related to a higher TSS levels within the 52-day period with a lower average floc size (Durante et al., 2006; Di Bella et al., 2007). Results again confirmed the reliability and consistency of the proposed method.

The general reproducibility of the method can be further appraised by extending the analysis of Cosenza et al. $(2013 \mathrm{a}, \mathrm{b})$ on the pilot plant $\mathrm{MBR}_{4}$, for which periodic physical cleaning was conducted during operation. In this case, the pilot plant was equipped with two identical membrane modules, designated $A$ and $B$, submerged in the same reactor and subjected to the same operating conditions (in terms of MLSS and EPS concentration, permeate flux and filtration time $t_{0}$ ). No evaluation of the resistance from conventional backwashing with mains water was possible since this was not conducted. Instead, only the first steps of the protocol (Section 2.1) could be applied (Eqs 1 and 2) so as to evaluate the overall cake resistance $R_{C}\left(R_{C, \text { irr }}+R_{C, \text { rev }}\right)$ and the irreversible contribution from intermediate blocking, originally defined as $R_{b}$ by Cosenza et al. Reproducibility of the measured specific resistance values between the two membranes was found to be very good, the difference being $<0.5 \cdot 10^{12} \cdot \mathrm{m}^{-1}$ and $<0.25 \cdot 10^{12} \cdot \mathrm{m}^{-1}$ for $R_{C}$ and $R_{P B}$ respectively according to Figure 4. Further fouling analysis was thus limited to one membrane module.

Finally, the fouling tendency of $\mathrm{MBR}_{5}$, equipped with FS modules, was investigated to assess the reliability of the method for this membrane configuration. The original specific objective of this pilot plant was to analyze fouling related to mixed liquor foaming (Di Bella et al., 2011) using the same resistance analysis as previous tests. Following pseudo steady-state conditions, two physical cleans were conducted for the same maintained mixed liquor characteristics: physical clean $A$ on Day 65 (5 days after the end of experiments), and physical clean $B$ on Day 70 (10 days after foaming study). The results (Figure 5) confirmed reproducibility to be satisfactory, with similar specific resistances determined following an identical filtration period under the same operating conditions, viz:

- Case $A: R_{t o t}=8.47 \cdot 10^{12} \mathrm{~m}^{-1} R_{C, \text { irr }}=1.06 \cdot 10^{12} \mathrm{~m}^{-1} ; R_{C, \text { rev }}=4.45 \cdot 10^{12} \mathrm{~m}^{-1} ; R_{P B}=0.41 \cdot 10^{12} \mathrm{~m}^{-1}$.

- Case $B: R_{t o t}=8.27 \cdot 10^{12} \mathrm{~m}^{-1} R_{C, i r r}=0.77 \cdot 10^{12} \mathrm{~m}^{-1} ; R_{C, r e v}=4.48 \cdot 10^{12} \mathrm{~m}^{-1} ; R_{P B}=0.47 \cdot 10^{12} \mathrm{~m}^{-1}$.

The outcomes demonstrate that the consistency of the manual washing method is not impaired by the differing characteristics of the cakes formed on FS and HF MBR modules, with the former tending to be thicker and more compact (Sioutopoulos and Karabelas, 2015) due to the reduced cleaning frequency associated with the absence of backwashing. Under such conditions, reversible fouling is sometimes defined as the superficial fouling $\left(R_{C, r e v}\right)$ removed by the continuous air scouring (Jiang et al., 2003, 2015). The remaining portion is then denoted irreversible fouling, but is removable with water rinsing or soft panel scrubbing such that intermediate fouling correlates with the fraction not removed by supplementary physical cleaning. Therefore, the dual measurement following cleaning, i.e. the resistance to clean water $\left(R_{t o t, c w}\right)$ and to the reactor mixed liquor $\left(R_{t o t, 2}\right)$, permits the true delineation between irreversible (mainly internal) pore blocking (partially removable with chemical cleaning only) fouling and that due to superficial, reversible deposition.

\subsubsection{Reproducibility, batch filtration tests}

Reproducibility was further explored based on three different filtration batch tests using two HF bench-scale membrane modules submerged in the same $15 \mathrm{~L}$ tank for a 15 -minute filtration time:

- $B T_{1}$ : filtration of real municipal wastewater $\left(\mathrm{COD} \approx 550 \mathrm{mg} \mathrm{L}^{-1} ; \mathrm{NH}_{4}-\mathrm{N} \approx 50 \mathrm{mg} \mathrm{L}^{-1} ; \mathrm{TSS} \approx\right.$ $0.42 \mathrm{~g} \mathrm{~L}^{-1}$ ) without suspended biomass operating with routine filtration/backwash cycles;

- $B T_{2}$ : filtration of mixed liquor deriving from the mixing of acclimated biomass and municipal wastewater fed in batch mode, operating with routine filtration/backwash cycles: 
- $B T_{3}$ : filtration of the $B T_{2}$ mixed liquor, operating without routine backwashing other than a single backwash at the end of test.

Results (Figure 6 and Table 2) indicate good reproducibility and confirm that the RIS model based on manual washing to successfully delineate the specific resistances. The individual resistance components differ by less than $0.1 \cdot 10^{12} \mathrm{~m}^{-1}$, and the batch tests confirm the fouling development to be in full agreement with that expected on the basis of the mechanisms reported in the literature (Meng et al., 2017), as listed in Table 4. For municipal wastewater $\left(B T_{1}\right)$, at low TSS concentrations compared to those of MBR MLSS, a rapid increase in total resistance was observed ascribed to irreversible internal fouling $\left(R_{P B}\right)$ deriving from the absence of the protective cake layer formed by the MLSS flocs. In this case backwashing with permeate had no significant impact, such that the filtration resistance increased unabated (Figure 6a) indicating complete irreversibility. The small difference in the absolute resistance values could be attributed to the difference in the clean membrane resistance ( $3.0 \times 10^{12} \mathrm{~m}^{-1}$ and $3.3 \times 10^{12} \mathrm{~m}^{-1}$ for $R_{m, A}$ and $R_{m, B}$ respectively). Conversely, the filtration test carried out with MLSS $\left(B T_{2}\right.$, Figure $\left.6 \mathrm{~b}\right)$, indicated the main resistance to be related to reversible superficial deposition $\left(R_{C, r e v}\right)$, with $R_{P B}$ and $R_{C, i r r}$ being insignificant. This result is indicative of the pre-filtering effect of the MLSS floc solids cake layer (Le Clech et al., 2006; Di Trapani et al., 2014), which results in a low mean resistance over the 15 minutes and provides a cake layer which is readily removed by backwashing to leave the residual resistance. The mean resistance for $B T_{1}$ after 15 minutes filtration $R_{\text {tot }}$ was $8.40 \times 10^{12} \mathrm{~m}^{-1}$ (Table 2) with the resistance due to pore blocking representing the main fouling contributor $\left(R_{P B}=5.14 \times 10^{12} \mathrm{~m}^{-1}\right)$, whilst the contribution due to cake (either reversible or irreversible) was almost negligible $\left(\mathrm{R}_{\mathrm{C}}=0.11 \times 10^{12}\right.$ $\mathrm{m}^{-1}$ ). In contrast, for $B T_{2}$ the $R_{t o t}$ value was almost half the $B T_{1}$ value at $4.70 \times 10^{12} \mathrm{~m}^{-1}$, where as pore blocking was negligible $\left(R_{P B}=0.07 \times 10^{12} \mathrm{~m}^{-1}\right)$ and reversible fouling through cake formation $\left(R_{C, \text { rev }}=1.41 \times 10^{12} \mathrm{~m}^{-1}\right)$ was the main contributor.

Table 2: Average values of the specific resistance $\left(\mathrm{m}^{-1}\right)$ achieved in the filtration batch tests.

\begin{tabular}{l|cccccc}
\hline & $R_{T}$ & $R_{m}$ & $R_{C, \text { rev }}$ & $R_{C, \text { irr }}$ & $R_{P B}$ & $\Delta R_{B W}$ \\
\hline $\mathrm{BT}_{1}$ & $8.40 \times 10^{12}$ & $3.15 \times 10^{12}$ & $0.11 \times 10^{12}$ & $0.00 \times 10^{12}$ & $5.14 \times 10^{12}$ & $+0.70 \times 10^{12}$ \\
$\mathrm{BT}_{2}$ & $4.70 \times 10^{12}$ & $3.15 \times 10^{12}$ & $1.41 \times 10^{12}$ & $0.08 \times 10^{12}$ & $0.07 \times 10^{12}$ & $-0.40 \times 10^{12}$ \\
$\mathrm{BT}_{3}$ & $9.36 \times 10^{12}$ & $3.15 \times 10^{12}$ & $5.55 \times 10^{12}$ & $0.44 \times 10^{12}$ & $0.25 \times 10^{12}$ & - \\
\hline
\end{tabular}

For the $B T_{3}$ trial, similar to $B T_{2}$ but operated without routine backwashing, the development of both reversible and irreversible fouling was observed, despite the $R_{C, \text { rev }}$ (evaluated based on the final backwashing) being the main fouling contributor. Despite the short filtration time (15 minutes) the absence of backwashing led to the development of secondary fouling (irreversible adsorption, etc.) with a partial penetration of the membrane pores. Despite the short filtration period the effect on the resistance was significant, with instantaneous resistances rapidly and continuously increasing (Figure 6c) to reach values higher than those recorded for $B T_{2}$.

A summary of the mean resistance values across all tests (Table 2) confirms the significant cake layer contribution to the total resistance in the case of the MBR membrane, compared with filtration of the raw wastewater $\left(B T_{1}\right)$. The average resistance variation after the ordinary backwashing $\left(\Delta R_{B W}\right)$ reveals that routine backwashing has no impact when filtering the raw feed water since the main fouling mechanism was the irreversible pore blocking $\left(R_{P B}\right)$, with a positive resistance variation $\left(\Delta R_{B W}=0.70 \times 10^{12} \mathrm{~m}^{-1}\right)$. In contrast, the results for $B T_{2}$ indicate a negative impact $\left(\triangle R_{B W}=\right.$ $-0.40 \times 10^{12} \mathrm{~m}^{-1}$ ) after backwashing associated with reversible cake deposition largely removed by the routine backwashing.

\subsection{Comparison with literature data}

The delineation of fouling resistance in the literature has been inconsistent across all studies, with a number of different definitions of the individual contributors and different attributions to the 
standard deposition/blocking filtration mechanisms (Table 3). Generally, fouling is delineated according to location, specifically external (cake deposition, $R_{C}$ ) or internal (pore blocking, $R_{P B}$ ) to the membrane. A proportion of these contributors may then be ascribed as reversible or irreversible with respect to physical cleaning, and the challenge is then presented by the delineation of irreversible/irrecoverable fouling from the residual membrane resistance through the action of chemical cleaning.

Table 3: $\quad$ Specific resistances defined in the total resistance decomposition

\begin{tabular}{|c|c|c|c|}
\hline Resistance & Resistance description & $\begin{array}{l}\text { Main mechanistic } \\
\text { attribution }\end{array}$ & References \\
\hline$R_{a d}$ & $\begin{array}{l}\text { Adsorption of particles matter onto the } \\
\text { membrane }\end{array}$ & $\begin{array}{l}\text { Intermediate } \\
\text { blocking }\end{array}$ & $\begin{array}{l}\text { Choi et al. 2005a e 2005b; } \\
\text { Busch et al., } 2007\end{array}$ \\
\hline$R_{b}$ & Blocking phenomenon & Standard blocking & Jiang et al., 2003 \\
\hline$R_{c}$ & Cake deposition & Cake deposition & $\begin{array}{l}\text { Lee et al., 2003; Meng et al., } \\
2005 a ; \text { Wintgens et al., 2003; } \\
\text { Ludwig et al., } 2011\end{array}$ \\
\hline$R_{b w}$ & $\begin{array}{l}\text { Irreversible fouling of dissolved matter } \\
\text { and colloids. }\end{array}$ & $\begin{array}{l}\text { Intermediate } \\
\text { blocking }\end{array}$ & Jiang et al., 2003 \\
\hline$R_{\text {irb }}$ or $R_{b}$ & $\begin{array}{l}\text { Internal irreversible fouling or internal } \\
\text { blocking }\end{array}$ & Complete blocking & $\begin{array}{l}\text { Jiang et al., 2003; } \\
\text { Broeckmann et al., } 2006\end{array}$ \\
\hline$R_{\text {irc }}$ & Superficial irreversible deposition & $\begin{array}{l}\text { Intermediate } \\
\text { blocking }\end{array}$ & Jiang et al., 2003 \\
\hline$R_{\text {reb }}$ & $\begin{array}{l}\text { Superficial reversible fouling or internal } \\
\text { blocking }\end{array}$ & $\begin{array}{l}\text { Intermediate } \\
\text { blocking }\end{array}$ & Jiang et al., 2003 \\
\hline$R_{\text {rec }}$ & Internal reversible fouling & Cake deposition & Jiang et al., 2003 \\
\hline$R_{c o}$ & $\begin{array}{l}\text { Resistance do to internal deposition of } \\
\text { colloids }\end{array}$ & Standard blocking & $\begin{array}{l}\text { Wisniewski and Grasmick } \\
\text { (1998); Jiang et al., } 2003\end{array}$ \\
\hline$R_{c p}$ & Concentration polarization & $\begin{array}{l}\text { Intermediate } \\
\text { blocking }\end{array}$ & $\begin{array}{l}\text { Choi et al. } 2005 \text { a e } 2005 b ; \\
\text { Busch et al., } 2007\end{array}$ \\
\hline$R_{f}$ & Resistance of "Pore fouling" & Pore blocking & $\begin{array}{l}\text { Lee et al., 2003; Meng et al., } \\
2005 b ; \\
\text { Wintgens et al., 2003, Chu e } \\
\text { Li, } 2005\end{array}$ \\
\hline$R_{p}$ & Irreversible pore blocking & Pore blocking & $\begin{array}{l}\text { Bowen et al., 1995; Chu e Li } \\
\text { 2005; Li and Wang, 2006; } \\
\text { Broeckmann et al., } 2006\end{array}$ \\
\hline$R_{P B}$ & Simple pore blocking & Pore blocking & $\begin{array}{l}\text { Lee et al., 2003; Meng et al., } \\
2005 a ; \text { Diez et al., } 2014\end{array}$ \\
\hline$R_{s c}$ & $\begin{array}{l}\text { Dynamic deposition of reversible } \\
\text { biofouling }\end{array}$ & $\begin{array}{l}\text { Intermediate } \\
\text { blocking }\end{array}$ & $\begin{array}{l}\text { Chu e Li 2005; Li e Wang } \\
2006\end{array}$ \\
\hline$R_{s f}$ & $\begin{array}{l}\text { Persistent deposition of irreversible } \\
\text { biofouling }\end{array}$ & Standard blocking & $\begin{array}{l}\text { Chu e Li (2005); Li e Wang } \\
\text { nel } 2006\end{array}$ \\
\hline$R_{\text {rev }}$ or $R_{r f}$ & Reversible fouling mechanism & $\begin{array}{l}\text { Cake deposition } \\
\text { intermediate } \\
\text { blocking }\end{array}$ & Diez et al., 2014 \\
\hline$R_{\text {irr }}$ or $R_{\text {if }}$ & Irreversible fouling mechanism & $\begin{array}{l}\text { Pore blocking } \\
\text { intermediate } \\
\text { blocking }\end{array}$ & Diez et al., 2014 \\
\hline
\end{tabular}


Table 4: Quantitative values of specific resistances defined in the total resistance decomposition

\begin{tabular}{|c|c|c|c|c|c|c|c|c|c|}
\hline \multirow[t]{3}{*}{ REFERENCE } & \multirow{3}{*}{$\begin{array}{c}\text { Flux } \\
\mathrm{L} \mathrm{m}^{-2} \mathrm{~h}^{-1}\end{array}$} & \multicolumn{2}{|c|}{ Backwashing } & \multirow{2}{*}{$\begin{array}{l}\text { Mixed Liquor } \\
\text { Main features } \\
\end{array}$} & \multirow[t]{2}{*}{$\mathbf{R}_{\mathrm{TOT}}$} & \multicolumn{2}{|c|}{$\mathbf{R}_{\mathbf{C}}$} & \multirow[t]{2}{*}{$\mathbf{R}_{\mathbf{P B}}$} & \multirow[t]{2}{*}{$\mathbf{R}_{\mathbf{m}}$} \\
\hline & & Filtration & Backwas. & & & $\mathrm{R}_{\mathrm{C}, \mathrm{rev}}$ & $\mathrm{R}_{\mathrm{C}, \mathrm{irr}}$ & & \\
\hline & & (min:sec) & (min:sec) & & $\mathrm{m}^{-1}$ & $\mathrm{~m}^{-1}$ & $\mathrm{~m}^{-1}$ & $\mathrm{~m}^{-1}$ & $\mathrm{~m}^{-1}$ \\
\hline \multicolumn{10}{|l|}{ Filtration test } \\
\hline \multirow[t]{3}{*}{ This study } & \multirow{3}{*}{25.0} & 04:00 & 01:00 & \multirow{3}{*}{ See Table 1} & $8.3-8.5 \times 10^{12}$ & $0.1-0.6 \times 10^{12}$ & $0.0 \times 10^{12}$ & $5.1-5.2 \times 10^{12}$ & $3.0 \times 10^{12}$ \\
\hline & & 04:00 & 01:00 & & $4.6-4.7 \times 10^{12}$ & $1.2-1.6 \times 10^{12}$ & $0.0-0.1 \times 10^{12}$ & $0.0-0.2 \times 10^{12}$ & $3.1 \times 10^{12}$ \\
\hline & & continuous & without & & $9.2-9.5 \times 10^{12}$ & $5.4-5.7 \times 10^{12}$ & $0.4-0.5 \times 10^{12}$ & $0.0-0.1 \times 10^{12}$ & $3.3 \times 10^{12}$ \\
\hline \multirow{3}{*}{ Kayaalp et al. (2013) } & \multirow{3}{*}{$\begin{array}{l}20.0 \\
\text { initial } \\
\text { value }\end{array}$} & 180 & Relaxion & MLSS about $9 \mathrm{~g} / \mathrm{L}$ & $3.20 \times 10^{12}$ & \multirow{2}{*}{\multicolumn{2}{|c|}{$\frac{2.40 \times 10^{12}}{2.60 \times 10^{12}}$}} & $\mathrm{R}_{\text {ir }}=0.64 \times 10^{12}$ & $0.20 \times 10^{12}$ \\
\hline & & 720 & Backwashing & $\mathrm{SRT}=20$ day & $3.60 \times 10^{12}$ & & & $\mathrm{R}_{\text {irr }}=0.79 \times 10^{12}$ & $0.21 \times 10^{12}$ \\
\hline & & 1440 & $\begin{array}{l}\text { only for } \\
\text { exceptional } \\
\text { cleaning }\end{array}$ & $\begin{array}{l}\text { Temperature fixed }=25^{\circ} \mathrm{C} \\
\text { EPSs }=600 \mathrm{mg} / \mathrm{L}\end{array}$ & $4.03 \times 10^{12}$ & \multicolumn{2}{|c|}{$3.10 \times 10^{12}$} & $\mathrm{R}_{\mathrm{irr}}=0.75 \times 10^{12}$ & $0.18 \times 10^{12}$ \\
\hline \multicolumn{10}{|l|}{ Bench Scale } \\
\hline \multirow{3}{*}{$\begin{array}{l}\text { MBR2A } \\
\text { MBR2B }\end{array}$} & \multirow{3}{*}{23.6} & 04:00 & 01:00 & \multirow{3}{*}{ See table 1} & $15.4-15.9 \times 10^{12}$ & $1.2-1.3 \times 10^{12}$ & $8.4-9.0 \times 10^{12}$ & $2.6-2.7 \times 10^{12}$ & $3.0 \times 10^{12}$ \\
\hline & & 04:00 & 01:00 & & $4.2-4.9 \times 10^{12}$ & $0.1-0.3 \times 10^{12}$ & $1.2-1.6 \times 10^{12}$ & $0.0-0.1 \times 10^{12}$ & $3.0 \times 10^{12}$ \\
\hline & & 09:00 & 01:00 & & $13.1-14.2 \times 10^{12}$ & $0.2-0.3 \times 10^{12}$ & $4.6-6.0 \times 10^{12}$ & $3.4-3.7 \times 10^{12}$ & $3.0 \times 10^{12}$ \\
\hline Khalili-Garakani et al. (2011) & 16.4 & continuous & without & $\begin{array}{l}\text { MLSS }=10 \mathrm{~g} / \mathrm{L} \\
\mathrm{HRT}=6.67 \mathrm{~h} \\
\text { SRT }=\text { complete retention } \\
\text { Temperature fixed }=19.9^{\circ} \mathrm{C} \\
\text { Superficial air velocity }(\mathrm{mm} / \mathrm{s}): 26.45\end{array}$ & $7.63 \times 10^{12}$ & \multicolumn{2}{|c|}{$\mathrm{R}_{\mathrm{C}}=4.66 \times 10^{12}$} & $0.38 \times 10^{12}$ & $0.26 \times 10^{12}$ \\
\hline \multirow[b]{2}{*}{ Deng et al. (2015) } & \multirow[b]{2}{*}{12.0} & \multirow[b]{2}{*}{ 664:00 } & \multirow[b]{2}{*}{ 02:00 } & \multirow{2}{*}{$\begin{array}{l}\text { MLSS }=15,2 \mathrm{~g} / \mathrm{L} \\
\mathrm{HRT}=6.67 \mathrm{~h} \\
\mathrm{SRT}=\text { complete SRT } \\
\text { EPSs } 35-70 \mathrm{mg} / \mathrm{L} \text { mainly bound }] \\
\text { EPSs } 20-80 \mathrm{mg} / \mathrm{L} \text { mainly smp }] \\
\text { air flowrate: } 9-10 \mathrm{~L} / \mathrm{min}\end{array}$} & $4.05 \times 10^{12}$ & \multicolumn{2}{|c|}{$\mathrm{R}_{\mathrm{C}}=3.00 \times 10^{12}$} & $1.50 \times 10^{12}$ & $0.90 \times 10^{12}$ \\
\hline & & & & & $3.54 \times 10^{12}$ & \multicolumn{2}{|c|}{$\mathbf{R}_{\mathrm{C}}=\mathbf{1 . 9 4} \times 10^{12}$} & $\mathbf{0 . 7 0} \times 10^{12}$ & $\mathbf{0 . 9 0 \times 1 0 ^ { 1 2 }}$ \\
\hline \multicolumn{10}{|l|}{ Pilot plant } \\
\hline \multirow[t]{3}{*}{ This study } & \multirow[t]{3}{*}{23.6} & 09:00 & 01:00 & & $3.78 \times 10^{12}$ & $1.12 \times 10^{12}$ & $0.12 \times 10^{12}$ & $2.09 \times 10^{12}$ & $0.45 \times 10^{12}$ \\
\hline & & 09:00 & 01:00 & See Table 1 & $1.61 \times 10^{12}$ & $0.28 \times 10^{12}$ & $0.11 \times 10^{12}$ & $0.98 \times 10^{12}$ & $0.24 \times 10^{12}$ \\
\hline & & 09:00 & 01:00 & & $7.38 \times 10^{12}$ & 5.86 & $\times 10^{12}$ & $1.30 \times 10^{12}$ & $0.22 \times 10^{12}$ \\
\hline Mannina et al. (2016b) & 21.0 & 09:00 & 01:00 & $\begin{array}{l}\text { MLSS }=5.75 \mathrm{~g} / \mathrm{L} \\
\mathrm{C} / \mathrm{N}=10\end{array}$ & $30.76 \times 10^{12}$ & $0.11 \times 10^{12}$ & $29.70 \times 10^{12}$ & $0.37 \times 10^{12}$ & $0.58 \times 10^{12}$ \\
\hline & & & & $\begin{array}{l}\mathrm{MLSS}=5.31 \mathrm{~g} / \mathrm{L} \\
\mathrm{C} / \mathrm{N}=5\end{array}$ & $30.73 \times 10^{12}$ & $0.33 \times 10^{12}$ & $29.37 \times 10^{12}$ & $0.45 \times 10^{12}$ & $0.58 \times 10^{12}$ \\
\hline & & 59:45 & $00: 05$ & MLSS $=6.6-6.8 \mathrm{~g} / \mathrm{L}$ & $7.48 \times 10^{12}$ & & $\mathrm{R}_{\mathrm{f}}=\mathrm{R}_{\mathrm{C}}+\mathrm{R}_{\mathrm{PB}}=6.53$ & $10^{12}$ & $0.95 \times 10^{12}$ \\
\hline Yigit et al. (2009) & 20.0 & 09:45 & $00: 15$ & $\begin{array}{l}\mathrm{HRT}=13-15 \mathrm{~h} \\
\mathrm{SRT}=\text { complete retention } \\
\text { Temperature fixed }=12^{\circ} \mathrm{C} \\
\text { air flowrate: } 42.5 \mathrm{~L} / \mathrm{min}\end{array}$ & $4.95 \times 10^{12}$ & & $\mathrm{R}_{\mathrm{f}}=\mathrm{R}_{\mathrm{C}}+\mathrm{R}_{\mathrm{PB}}=4.00$ & $10^{12}$ & $0.95 \times 10^{12}$ \\
\hline
\end{tabular}


Reported values of the different resistance contributors (Table 4) indicate a more than two orders of magnitude variation in the $R_{C, \text { rev }}$ or $R_{C}$ cake resistance values, from 0.1 to $30 \times 10^{12} \mathrm{~m}^{-1}$, across the selected studies due to differences in permeate flux, backwash frequency, flux and duration, and mixed liquor characteristics. This compares to a variation of around one order of magnitude for the residual membrane resistance $\left(0.2\right.$ to $\left.3 \times 10^{12} \mathrm{~m}^{-1}\right)$, reflecting differences in both the irreversible fouling and virgin membrane surface characteristics. Notwithstanding this, the quantitative cake layer resistance values recorded in the current study are within the range of those reported previously.

However, very few previous studies have delineated the reversible and irreversible component of the cake fouling, i.e. $R_{C \text {,rev }}$ or $R_{C, i r r}$. The delineation of the irreversible contribution allows the permeability recovery generated through enhanced physical cleaning to be determined. Against this, the persistence of irreversible fouling influences the prefiltration effect which may ameliorate fouling through pre-filtration or exacerbate it through superficial occlusion, depending on its characteristics. Consequently, the resistance due to pore blocking $\left(R_{P B}\right)$ may be low or high, with reduced pore blocking and a higher cake resistance when prefiltration takes place and the converse when it does not. The latter is particularly evident for gelatinous sludge (Mannina et al., 2016a) and/or when high levels of EPS persist (Jørgensen et al., 2017).

The proposed approach enables a more accurate comprehension of the physical cleaning effects on all contributions to the RIS model compared to the more simplistic approaches (Verberk and van Dijk, 2003; Meng et al., 2005a; Liang et al., 2008). The improved comprehension of fouling tendency may then inform optimization of the physical/chemical cleaning methods and their frequency of application.

\section{Conclusions}

The application of a modified physical cleaning method for in-depth fouling analysis was studied to elucidate the different fouling mechanisms through RIS model application. Reproducibility of the method across eight different MBR installations at bench and pilot scale was shown to be very good, with an average percentage difference between duplicated tests being below 14\%). This simple method provided trends which were consistent with those reported in the literature for data based on classical methods, but with added insight into fouling mechanisms and, specifically, the relative contributions of the different foulant contributors generally and the delineation of reversible and irreversible fouling. The method has been successfully demonstrated on bench and pilot scale systems, and can be used to determine appropriate physical/chemical cleaning protocols for sustaining membrane permeability and potentially extending membrane service life.

\section{REFERENCES}

[1] Z. Wang, J. Ma, C.Y. Tang, K. Kimura, Q. Wang, X. Han, Membrane cleaning in membrane bioreactors: A review, J. Memb. Sci. 468 (2014) 276-307.

[2] C. Huyskens, S. Lenaerts, E. Brauns, L. Diels, H. De Wever, Study of (ir)reversible fouling in MBRs under various operating conditions using new on-line fouling sensor, Sep. Purif. Technol. 81 (2011) 208-215.

[3] H. Liang, W. Gong, J. Chen, G. Li, Cleaning of fouled ultrafiltration (UF) membrane by algae during reservoir water treatment, Desalination. 220 (2008) 267-272.

[4] G. Di Bella, N. Di Prima, D. Di Trapani, G. Freni, M.G. Giustra, M. Torregrossa, et al., Performance of membrane bioreactor (MBR) systems for the treatment of shipboard slops: Assessment of hydrocarbon biodegradation and biomass activity under salinity variation, J. Hazard. Mater. 300 (2015) 765-778. 
[5] D. Li, M. Li, Y. Wang, C. Gong, Optimization of the operating parameters for online ultrasonic on controlling membrane fouling in SMBR, Desalin. Water Treat. 51 (2013).

[6] K. Chatzikonstantinou, N. Tzamtzis, A. Pappa, S. Liodakis, Membrane fouling control using high-frequency power vibration, in an SMBR pilot system-preliminary studies, Desalin. Water Treat. 57 (2016) 11550-11560.

[7] S. Rosenberger, F.P. Helmus, S. Krause, A. Bareth, U. Meyer-Blumenroth, Principles of an enhanced MBR-process with mechanical cleaning, Water Sci. Technol. 64 (2011) 1951-1958.

[8] S.N. Shim, S.R. Kim, S.J. Jo, K.M. Yeon, C.H. Lee, Evaluation of mechanical membrane cleaning with moving beads in MBR using Box-Behnken response surface methodology, Desalin. Water Treat. 56 (2015) 2797-2806.

[9] M. Aslam, A. Charfi, G. Lesage, M. Heran, J. Kim, Membrane bioreactors for wastewater treatment: A review of mechanical cleaning by scouring agents to control membrane fouling, Chem. Eng. J. 307 (2017) 897-913.

[10] P. Le-Clech, V. Chen, T.A.G. Fane, Fouling in membrane bioreactors used in wastewater treatment, J. Memb. Sci. 284 (2006) 17-53.

[11] E. Scholes, V. Verheyen, P. Brook-Carter, A review of practical tools for rapid monitoring of membrane bioreactors, Water Res. 102 (2016) 252-262.

[12] F. Meng, S. Zhang, Y. Oh, Z. Zhou, H.S. Shin, S.R. Chae, Fouling in membrane bioreactors: An updated review, Water Res. 114 (2017) 151-180.

[13] T. Jiang, M.D. Kennedy, W.G.J. van der Meer, P.A. Vanrolleghem, J.C. Schippers, The role of blocking and cake filtration in MBR fouling, Desalination. 157 (2003) 335-343.

[14] G. Mannina, A. Cosenza, D. Di Trapani, M. Capodici, G. Viviani, Membrane bioreactors for treatment of saline wastewater contaminated by hydrocarbons (diesel fuel): An experimental pilot plant case study, Chem. Eng. J. 291 (2016) 269-278..

[15] G. Mannina, M. Capodici, A. Cosenza, D. Di Trapani, Carbon and nutrient biological removal in a University of Cape Town membrane bioreactor: Analysis of a pilot plant operated under two different C/N ratios, Chem. Eng. J. 296 (2016) 289-299.

[16] C. Psoch, S. Schiewer, Direct filtration of natural and simulated river water withair sparging and sponge ball application for fouling control, Desalination. 197 (2006) 190-204.

[17] B. Rafiei, F. Naeimpoor, T. Mohammadi, Bio-film and bio-entrapped hybrid membrane bioreactors in wastewater treatment: Comparison of membrane fouling and removal efficiency, Desalination. 337 (2014) 16-22.

[18] I.-S. Chang, S.-O. Bag, C.-H. Lee, Effects of membrane fouling on solute rejection during membrane filtration of activated sludge, Process Biochem. 36 (2001) 855-860.

[19] I.-S. Chang, R. Field, Z. Cui, Limitations of resistance-in-series model for fouling analysis in membrane bioreactors: A cautionary note, Desalin. Water Treat. 8 (2009) 31-36.

[20] G. Di Bella, F. Durante, M. Torregrossa, G. Viviani, Start-up with or without inoculum? Analysis of an SMBR pilot plant, DES. 260 (2010) 79-90.

[21] G. Di Bella, M. Torregrossa, G. Viviani, The role of EPS concentration in MBR foaming: Analysis of a submerged pilot plant, Bioresour. Technol. 102 (2011) 1628-1635.

[22] G. Di Bella, D. Di Trapani, M. Torregrossa, G. Viviani, Performance of a MBR pilot plant treating high strength wastewater subject to salinity increase: Analysis of biomass activity and fouling behaviour, Bioresour. Technol. 147 (2013) 614-618.

[23] D. Di Trapani, G. Di Bella, G. Mannina, M. Torregrossa, G. Viviani, Comparison between moving bed-membrane bioreactor (MB-MBR) and membrane bioreactor (MBR) systems: Influence of wastewater salinity variation, Bioresour. Technol. 162 (2014) 60-69.

[24] D. Di Trapani, G. Di Bella, G. Mannina, M. Torregrossa, G. Viviani, Effect of C/N shock variation on the performances of a moving bed membrane bioreactor, Bioresour. Technol. 189 (2015) 250-257.

[25] M. Kraume, D. Wedi, J. Schaller, V. Iversen, A. Drews, Fouling in MBR: What use are lab investigations for full scale operation?, Desalination. 236 (2009) 94-103. 
[26] B. Verrecht, S. Judd, G. Guglielmi, C. Brepols, J.W. Mulder, An aeration energy model for an immersed membrane bioreactor, Water Res. 42 (2008) 4761-4770.

[27] A. Cosenza, G. Di Bella, G. Mannina, M. Torregrossa, G. Viviani, Biological Nutrient Removal and Fouling Phenomena in a University of Cape Town Membrane Bioreactor Treating High Nitrogen Loads, J. Environ. Eng. 139 (2013) 773-780.

[28] A. Cosenza, G. Di Bella, G. Mannina, M. Torregrossa, The role of EPS in fouling and foaming phenomena for a membrane bioreactor, Bioresour. Technol. 147 (2013) 184-192.

[29] E. Reid, X. Liu, S.J. Judd, Effect of high salinity on activated sludge characteristics and membrane permeability in an immersed membrane bioreactor, J. Memb. Sci. 283 (2006) 164-171.

[30] H. Lin, M. Zhang, F. Wang, F. Meng, B.-Q. Liao, H. Hong, et al., A critical review of extracellular polymeric substances (EPSs) in membrane bioreactors: Characteristics, roles in membrane fouling and control strategies, J. Memb. Sci. 460 (2014) 110-125.

[31] A. Maartens, E.P. Jacobs, P. Swart, UF of pulp and paper effluent: Membrane foulingprevention and cleaning, J. Memb. Sci. 209 (2002) 81-92.

[32] I. Ruigómez, E. González, S. Guerra, L.E. Rodriguez-Gómez, L. Vera, Evaluation of a novel physical cleaning strategy based on HF membrane rotation during the backwashing/relaxation phases for anaerobic submerged MBR, J. Memb. Sci. 526 (2017) 181-190.

[33] F. Durante, G. Di Bella, M. Torregrossa, G. Viviani, Particle size distribution and biomass growth in a submerged membrane bioreactor, Desalination. 199 (2006) 493-495.

[34] G. Di Bella, F. Durante, M. Torregrossa, G. Viviani, P. Mercurio, A. Cicala, The role of fouling mechanisms in a membrane bioreactor, Water Sci. Technol. 55 (2007) 455-464.

[35] D.C. Sioutopoulos, A.J. Karabelas, The effect of permeation flux on the specific resistance of polysaccharide fouling layers developing during dead-end ultrafiltration, J. Memb. Sci. 473 (2015) 292-301.

[36] W. Jiang, Y. Wei, X. Gao, C. Gao, Y. Wang, An innovative backwash cleaning technique for NF membrane in groundwater desalination: Fouling reversibility and cleaning without chemical detergent, Desalination. 359 (2015) 26-36.

[37] F.G. Meng, H.M. Zhang, Y.S. Li, X.W. Zhang, F.L. Yang, J.N. Xiao, Cake layer morphology in microfiltration of activated sludge wastewater based on fractal analysis, Sep. Purif. Technol. 44 (2005) 250-257.

[38] H. Choi, K. Zhang, D.D. Dionysiou, D.B. Oerther, G.A. Sorial, Influence of cross-flow velocity on membrane performance during filtration of biological suspension, J. Memb. Sci. 248 (2005) 189-199.

[39] H. Choi, K. Zhang, D.D. Dionysiou, D.B. Oerther, G.A. Sorial, Effect of permeate flux and tangential flow on membrane fouling for wastewater treatment, Sep. Purif. Technol. 45 (2005) 6878.

[40] J. Busch, A. Cruse, W. Marquardt, Modeling submerged hollow-fiber membrane filtration for wastewater treatment, J. Memb. Sci. 288 (2007) 94-111.

[41] W. Lee, S. Kang, H. Shin, Sludge characteristics and their contribution to microfiltration in submerged membrane bioreactors, J. Memb. Sci. 216 (2003) 217-227.

[42] T. Wintgens, J. Rosen, T. Melin, C. Brepols, K. Drensla, N. Engelhardt, Modelling of a membrane bioreactor system for municipal wastewater treatment, J. Memb. Sci. 216 (2003) 55-65.

[43] T. Ludwig, D. Gaida, C. Keysers, J. Pinnekamp, M. Bongards, P. Kern, et al., An advanced simulation model for membrane bioreactors: development, calibration and validation., Water Sci Technol. 66 (2012) 1384-91.

[44] A. Broeckmann, J. Busch, T. Wintgens, W. Marquardt, Modeling of pore blocking and cake layer formation in membrane filtration for wastewater treatment, Desalination. 189 (2006) 97-109.

[45] C. Wisniewski, A. Grasmick, Floc size distribution in a membrane bioreactor and consequences for membrane fouling, Colloids Surfaces A Physicochem. Eng. Asp. 138 (1998) 403411. 
[46] F. Meng, H. Zhang, Y. Li, X. Zhang, F. Yang, Application of fractal permeation model to investigate membrane fouling in membrane bioreactor, J. Memb. Sci. 262 (2005) 107-116.

[47] H.P. Chu, X.-Y. Li, Membrane fouling in a membrane bioreactor (MBR): Sludge cake formation and fouling characteristics, Biotechnol. Bioeng. 90 (2005) 323-331.

[48] W.R. Bowen, J.I. Calvo, A. Hernández, Steps of membrane blocking in flux decline during protein microfiltration, J. Memb. Sci. 101 (1995) 153-165.

[49] X. yan Li, X. mao Wang, Modelling of membrane fouling in a submerged membrane bioreactor, J. Memb. Sci. 278 (2006) 151-161.

[50] V. Diez, D. Ezquerra, J.L. Cabezas, A. García, C. Ramos, A modified method for evaluation of critical flux, fouling rate and in situ determination of resistance and compressibility in MBR under different fouling conditions, J. Memb. Sci. 453 (2014) 1-11.

[51] M.K. Jørgensen, M. Nierychlo, A.H. Nielsen, P. Larsen, M.L. Christensen, P.H. Nielsen, Unified understanding of physico-chemical properties of activated sludge and fouling propensity, Water Res. 120 (2017) 117-132.

[52] N. Kayaalp, C. Kinaci, N. Dizge, N. Hamidi, Correlation of filtration resistance with microbial polymeric substances extracted from membranes in a submerged membrane bioreactor, Clean - Soil, Air, Water. 42 (2014) 1712-1720.

[53] A. Khalili-Garakani, M.R. Mehrnia, N. Mostoufi, M.H. Sarrafzadeh, Analyze and control fouling in an airlift membrane bioreactor: CFD simulation and experimental studies, Process Biochem. 46 (2011) 1138-1145.

[54] L. Deng, W. Guo, H.H. Ngo, M.F.R. Zuthi, J. Zhang, S. Liang, et al., Membrane fouling reduction and improvement of sludge characteristics by bioflocculant addition in submerged membrane bioreactor, Sep. Purif. Technol. 156 (2015) 450-458.

[55] N. Yigit, G. Civelekoglu, I. Harman, H. Koseoglu, M. Kitis, Effects of various backwash scenarios on membrane fouling in a membrane bioreactor, in: Environ. Earth Sci., 2011: pp. 917929.

[56] J. Verberk, H. Van Dijk, Research on AirFlush: Distribution of water and air in tubular and capillary membrane modules, in: Water Sci. Technol. Water Supply, 2003: pp. 409-414. 